\title{
Nurses' Knowledge Regarding Prevention of Ventilator Associated Pneumonia
}

\author{
Aurang Zeb*, Muhammad Hasnain, Ijaz Ahmad, Shafiq Khan and Aftab Ali shah \\ Rehman College of Nursing Peshawar, Pakistan
}

Received: 無August 28,2018; Published: 海 September 06, 2018

*Corresponding author: Aurang Zeb, Rehman College of Nursing Peshawar, Pakistan

\begin{abstract}
Ventilator Associated Pneumonia (VAP) is one of the common nosocomial infections with the prevalence rate of $10 \%$ to $70 \%$ in Intensive Care Units (ICUs). The incidence of VAP is $22.8 \%$ in patients on mechanical ventilation. Nurse's lack of knowledge about infection prevention and proper nursing care may become barrier to Prevent VAP.
\end{abstract}

Aim: The Aim of this study is to explore nurse's knowledge regarding Prevention of VAP.

Methods: Cross-sectional-study was conducted at both public and private tertiary care hospitals in Peshawar from March to April 2018. Nurse's knowledge was assessed by using close-ended questionnaire from 100 Critical-care Nurses. Participants were selected through convenient sampling. The questionnaire was adopted from similar studies which included 15 questions. Data was analyzed using descriptive statistics by SPSS software version 22.

Results: This study consisted of 100 Participants including 30\% males and 70\% females. 33\% of the participants were married and $67 \%$ were unmarried. Professional qualification of participants was also identified, 53\% of the participants were diploma holders and $47 \%$ were generic BSN. The mean ICU experiences of participants were $2.79+3.0$ years. The mean Score in the knowledge part of VAP prevention out of 15 marks was $8.14+1.8$.

Conclusion: The study concludes that several educational programs shall be arranged for nurses to improve their knowledge of VAP prevention and can decrease Ventilator associated Pneumonia among patients.

\section{Introduction}

Pneumonia is described as an inflammation of lung that primarily affects alveoli McLuckie [1]; Leach \& Richard [2]. Pneumonia is usually caused by the infection with virus, bacteria and another microorganism McLuckie [1]; Jeffrey \&Pommerville [3]. Ventilator associated pneumonia (VAP) is one of the common nosocomial infections with the prevalence rate of $10 \%$ to $70 \%$ in critical care units Ruffell et al. [4]. Ventilator-associated pneumonia is a type of lungs infection that occurs in people on mechanical ventilator in hospitals. It typically affects source of increased illness and death. Patients with ventilator acquired pneumonia (VAP) have increased Stay-length in hospital and have up to a 20$30 \%$ death rate Cook [5]. The incidence of VAP is $22.8 \%$ in patients on mechanical ventilation in developed countries Safdar N [6]; Dezfulian [6]. Ventilator associated Pneumonia is mainly caused after aspiration when the pathogen is transmitted to critically ill Patients in intensive care unit Michetti et al. [7]. Aspiration causes
Oro-pharyngeal Colonization and infection. Most of the patients admitted in ICU are already colonized with bacterial infection Ruffell et al. [4]. Ventilator-associated Pneumonia (VAP) is the common nosocomial infection which mostly occurs in ICU's Patients on Mechanical Ventilation for 48 hours or longer; it increases hospital stay and financial cost of the Patients Cooper \& Haut [8]; Yazdani et al. [9]. Furthermore, VAP is also associated with prolonged ICU stay in hospital and delayed extubating, that increases morbidity and mortality rate El Khatib et al. [10]. The study "Critical Care Nurse's Knowledge of Ventilator-Associated Pneumonia Prevention in a Hospital in Khartoum" by Al Shameri [11] resulted that nurses have inadequate knowledge about VAP prevention.

Another study 'Critical Care Nurses' Knowledge and Compliance with Ventilator Associated Pneumonia Bundle at Cairo University Hospitals" in Cairo, Egypt by Nahla [12] indicates that all critical care nurses, with different educational levels, have 
unsatisfactory knowledge scores about ventilator associated pneumonia and VAP bundle preventive measure. A cross-sectional study "Knowledge Levels of Intensive Care Nurses on Prevention of Ventilator-associated Pneumonia" in Turkey by Korhan et al. [13] shows that critical care nurses have poor knowledge about ventilator associated Pneumonia. A descriptive study "Nurses' knowledge of evidence- based guidelines for preventing ventilator associated pneumonia in intensive care units" in Iran by Masoumeh Bagheri Nesam [14]; Amiri [14] quantified the result in percentages and showed that level of the nurses' knowledge about preventive measures was $51.92 \%$; they also recommended the need of more educational programs in the target field. A study to assess the knowledge and practice of intensive care nurses on prevention of ventilator-associated pneumonia (VAP) among patients admitted in critical care units of Government Medical College Hospitals, Jammu (J\&K), by Jyoti Kapoor [15] revealed that ICU nurses had average knowledge regarding ventilator acquired Pneumonia. A study on the same topic in Karachi, Pakistan by Yasmin et al. (2011) resulted that nurse working at critical unit were having knowledge-gap to be able to prevent VAP among ventilated patients.

\section{Nurses' role in prevention of VAP}

Critical care nurses play an important role in prevention of Ventilator associated Pneumonia by preventing patient from risk factors, notifying early symptoms of VAP in Patients and assisting in diagnosis Myrianthefs et al. [16]. Nurses are health care providers who protect patients from infection. So, lack of knowledge about the prevention of infection and proper nursing care may become barrier to prevent VAP. The occurrence of ventilator acquired Pneumonia indicates inadequacy of experienced nurses, insufficient knowledge and understanding about the pathophysiology and prevention of VAP. The spread of VAP may be due to ICU Nurses' contact with patients receiving care of mechanical ventilation and their contact with nursing students, visitors and health care workers. Moreover, they are responsible for delivering nursing care to patient. As nurses deliver care related to mechanical ventilation, they should have appropriate knowledge regarding ventilator moods, positive pressure ventilation, daily weaning process, aspiration prevention and head on the bed elevation. This knowledge should be integrated into Practice to Prevent VAP Keyt, Faverio, \& Res, [17].; Gonçalves et al. [18]. However, ventilator associated pneumonia is preventable by educating ICUs nurses regarding VAP. No study has been found on knowledge of intensive care nurses regarding prevention of VAP in KPK. Therefore, it is important to explore intensive care nurse's knowledge, and to highlight deficiency in knowledge for creating awareness and methods to prevent VAP in KPK which is the aim of this study.

\section{Purpose of the Study}

The purpose of this study is to explore nurses' knowledge regarding Prevention of VAP in order to prevent complications.

\section{Methodology}

Study Design: Descriptive cross-sectional was conducted at both public and private tertiary care hospitals in Peshawar from March to April 2018.

Population and Setting: Both public and private sector hospitals were selected for conducting this study. The population of this study was ICU Nurses in hospital.

Sampling Technique: Critical Care Nurses of different ICUs were selected by using Convenient Sampling technique.

Sample Size: Sample size is calculated by Rao soft software, with $5 \%$ margin of error and $10 \%$ non-response rate the proportionate sample obtained is given below. So, the total sample size from three hospitals is 100

Inclusion Criteria: Registered nurses working in ICUs

Exclusion Criteria: ICU nurses with less than six months of experience. Managerial nurses do not directly involve in patient care

Data Collection Tool: An adopted well- organized questionnaire was used for data collection (Ally Tatu Said, 2012); Labeau et al. [19]. The questionnaire contained fifteen questions about Prevention of Ventilator-acquired Pneumonia.

Ethical Consideration: Approval for the data collection was taken from the Hospital Directors. Written informed consent was presented to each participant for his/her agreement as a participant. Anonymity was guaranteed to all the participants. The whole data was kept confidential. Only primary data collectors and supervisors had access.

Data Analysis: Data was analyzed by using SPSS version 22. In descriptive statistics, frequencies and percentages were calculated for nominal and ordinal data while mean and standard deviation were calculated for continuous variables.

In inferential statistics paired $\mathrm{T}$ test was applied to identify the effectiveness of informed consent on preoperative anxiety.

\section{Result}

This study consisted of 100 participants including 30\% males and $70 \%$ females (Chart 1). 33\% of the participants were married and 67\% were unmarried (Table 1). As for as Academic qualification of the participants is concerned, $30 \%$ participants had Matric, and $70 \%$ participants had FA/FSC qualification. The mean experience of participants is $4.2+4.5$ years (Table 2 ). The mean ICU experience of participants is $2.79+3.0$ years (Table 3 ). The mean Score in the knowledge part of VAP prevention in the questionnaire of Participants is 8.1+1.8. Oneway ANNOVA and Independent T-test are applied to find out association between, Variables But no association found among variables. 


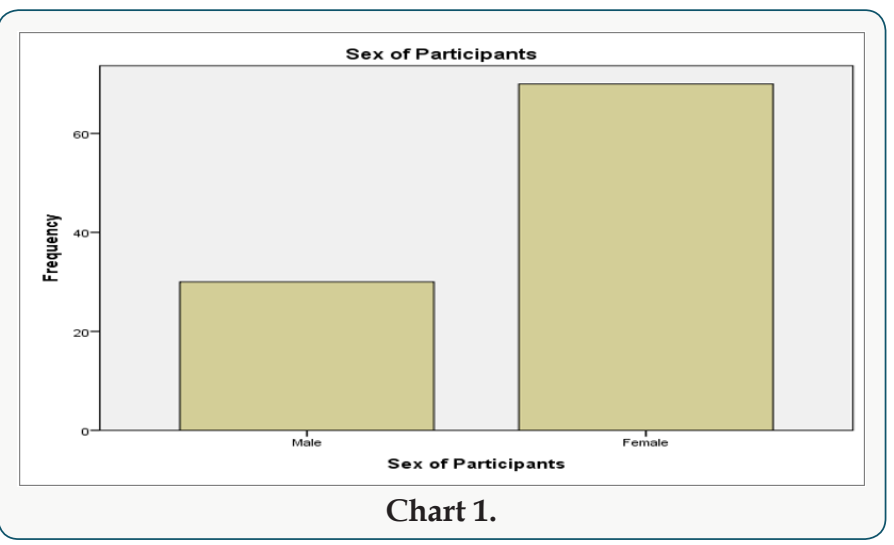

Table 1.

\begin{tabular}{|c|c|c|}
\hline & Frequency & Percent \\
\hline Married & 33 & 33 \\
\hline Unmarried & 67 & 67 \\
\hline Total & 100 & 100 \\
\hline
\end{tabular}

Table 2: Professional Qualification.

\begin{tabular}{|c|c|c|}
\hline & Frequency & Percent \\
\hline Diploma & 53 & 53 \\
\hline BSN & 47 & 47 \\
\hline Total & 100 & 100 \\
\hline
\end{tabular}

Table 3.

\begin{tabular}{|c|c|c|c|}
\hline & N & Mean & $\begin{array}{c}\text { Std. } \\
\text { Deviation }\end{array}$ \\
\hline Total experience & 100 & 4.27 & 4.5 \\
\hline ICU experience & 100 & 2.79 & 3 \\
\hline Score of participants & 100 & 8.14 & 1.8 \\
\hline
\end{tabular}

\section{Discussion}

Literature is available on the subject matter; studies have been conducted in different parts of the world. These studies show different results. Some of them are related to the result of current study. A study “Critical Care Nurse's Knowledge of VentilatorAssociated Pneumonia Prevention was done in Hospitals in Khartoum" by Al Shameri [11] in which data were collected through the use of structured knowledge questionnaire filled from 120 ICU nurses. The result showed that the overall knowledge of nurses regarding the VAP prevention mean was (18.22 from 40) that was a poor result (Chart 2). This shows us that most of the nurses have inadequate knowledge about VAP prevention. Another study “Critical Care Nurses' Knowledge and Compliance with Ventilator Associated Pneumonia Bundle at Cairo University Hospitals" in Cairo, Egypt was conducted by NahlaShaaban Ali (2013) in which data were collected from 45 ICU nurses through Self-administered questionnaire. The result showed that all critical care nurses with different educational levels, had unsatisfactory knowledge scores about ventilator associated pneumonia and VAP bundle preventive measure.
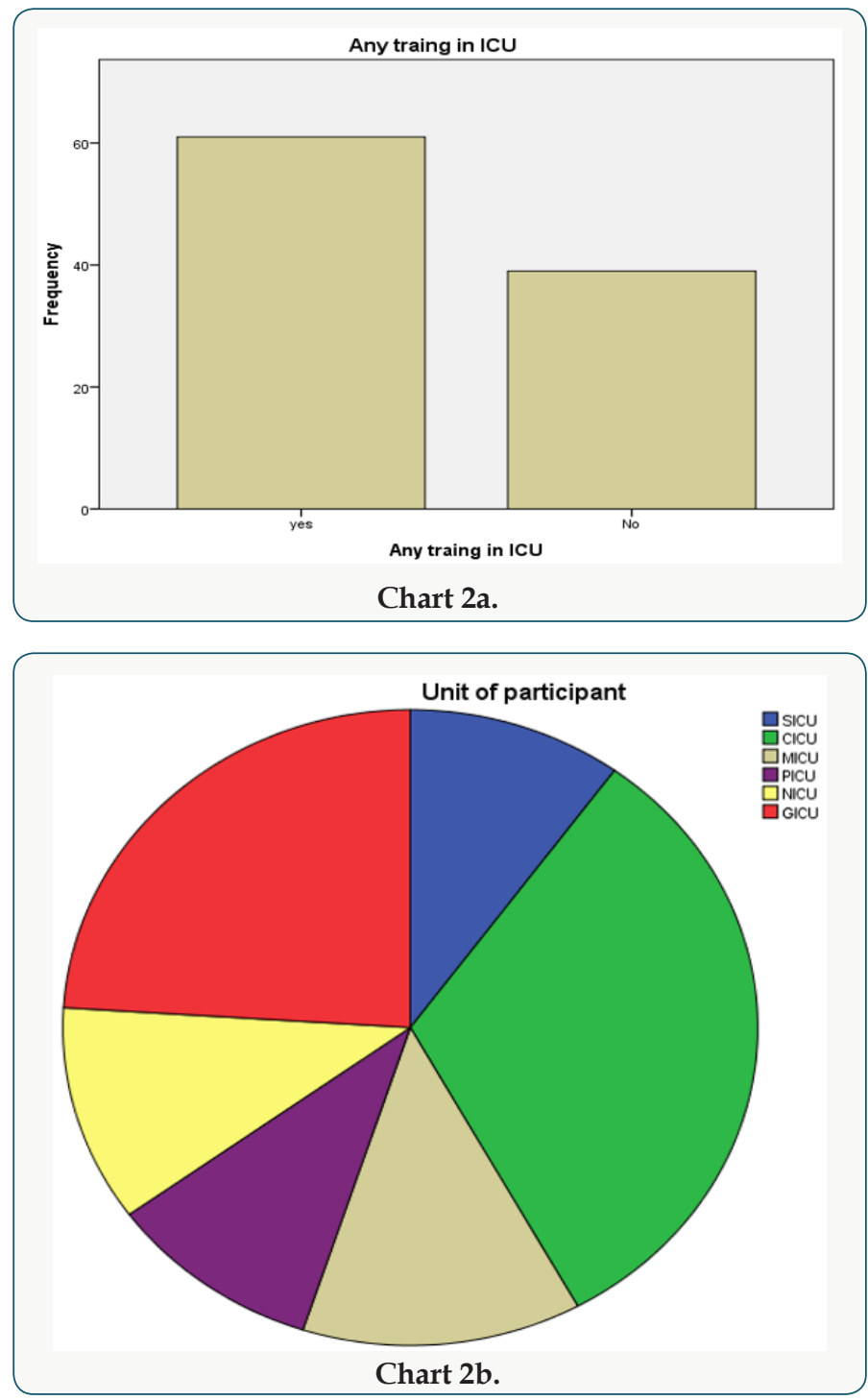

In cross-sectional study titled as "knowledge levels of intensive care nurses on prevention of ventilator-associated Pneumonia" in Turkey, Korhan et al. [13] collected data by means of a Nurse Identification Form and a Form of Evidence-Based Knowledge regarding the Prevention of Ventilator-Associated pneumonia; in that study, the findings were with the median value of total points scored by nurses on the questionnaire was $4.00 \pm 2.00$. And the median value of their total scores on the questionnaire was found to be statistically significant $(\mathrm{p}<0.05)$. The conclusion of the study was that critical care nurses' knowledge about ventilatorassociated pneumonia prevention was poor Korhan et al. [13]. In a descriptive study “Nurses' knowledge of evidence- based guidelines for preventing ventilator associated pneumonia in intensive care units" in Iran, Bagheri Nesami [14]; Amiri [14] assessed the knowledge of 52 ICU nurses through questionnaire, and they quantified the result in percentages which showed that showed the level of the nurses' knowledge about preventive measures was $51.92 \%$. They also recommended the need of more educational programs in this field. Similarly, Jyoti Kapoor [15] found that 'intensive care nurses have average knowledge and unsatisfactory 
practice regarding prevention of ventilator-associated pneumonia (Chart 3) [20].' While, the current study shows that among 100 ICU nurses, $88 \%$ nurses have average knowledge, $5 \%$ of them has excellent knowledge and 7\% nurses have poor knowledge about ventilator acquired pneumonia prevention [21].

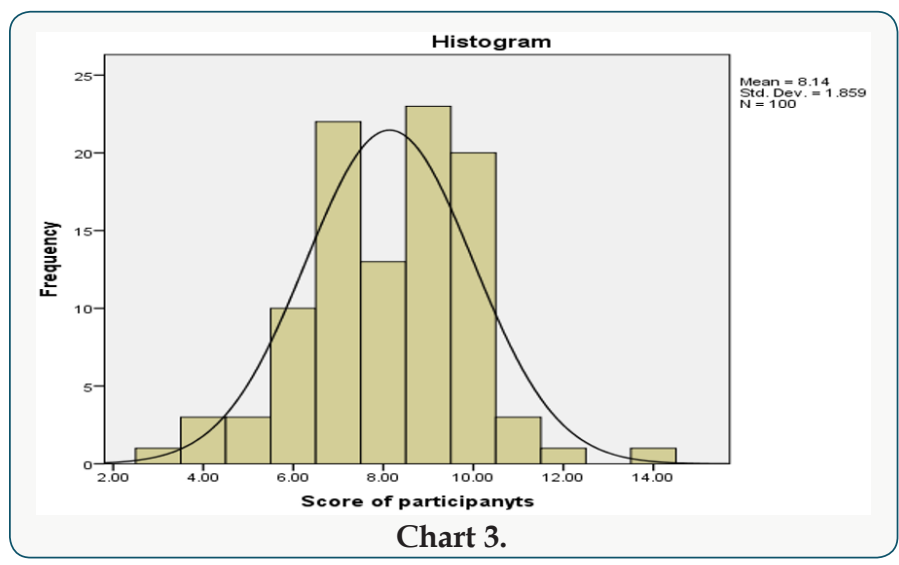

\section{Conclusion and Recommendations}

Current study revealed that $80 \%$ nurses of ICU have average knowledge; while, only 5\% nurses have excellent knowledge regarding VAP [22]. Thus, it is concluded that several educational programs should be arranged for nurses to improve their knowledge from average to excellent and to decrease Ventilator associated Pneumonia among patients.

\section{References}

1. Seleem MN, Boyle SN, Sriranganathan N (2010) Brucellosis: A reemerging zoonosis. Vet. Microbiology 140(3-4): 392-398.

2. McDermott JJ, Deng KA, Jayatileka TN, El Jack MA (1987) A crosssectional cattle disease study in Kongor rural council, southern Sudan: Prevalence estimates and age, sex and breed associations for brucellosis and contagious bovine pleuropneumonia. Preventive Veterinary Medicine 5(2): 111-123.

3. Ducrotoy MJ, Bertu WJ, Matope G, Cadmus S, Conde-Álvarez R, et al. (2015) Brucellosis in sub-Saharan Africa: Current challenges for management, diagnosis and control. Acta Tropica, p. 1-15.

4. Mangen MJ, Otte J, Pfeiffer D, Chilonda P (2003) A methodological framework for crude estimation of production losses attributable to diseases, using bovine brucellosis in sub-Saharan Africa as an example.

5. Domenech J, Coulomb J, Lucet L (1982) Bovine brucellosis in Central Africa: An evaluation of its economic incidence and a cost-benefit calculation of eradication campaigns. Revue D'élevage et de Médecine Vétérinaire Des Pays Tropicaux 35(2): 113-124.

6. Camus E (1984) Brucella vaccination of cows in northern Ivory Coast Developments in Biological Standardization 56: 755-757.

7. Böhnel H (1971) Recherches sur les causes de mortalité des veaux dans la savane sous-soudanienne du nord de la Cote d'Ivoire. Bull Epizoot Dis Afr 19(2): 145-157.
8. Camus E (1995) Evaluation of trypanosomiasis and brucellosis control in cattle herds of Ivory Coast. Agriculture and Human Values 12(2): 9094.

9. MIRAH (2012) Rapport national sur l'état des ressources zoogénétique. Ministère de la production animale et de ressources halieutiques. MIRAH-DPP. 2012. Annuaire des statistiques des ressources animales et halieutiques. Direction de la planification et des programmations, Ministère des ressources animales et halieutiques, Abidjan, Côte d'Ivoire, p. 26.

10. BNETD (2012) Rapport Du BNETD sur le marché du bétail et de la viande en Côte d'Ivoire: Analyse des circuits d'approvisionnement, évolution des coûts et des prix du bétail et de la viande.

11. Kanouté YB, Gragnon BG, Schindler C, Bonfoh B, Schelling E (2017) Epidemiology of brucellosis, $\mathrm{Q}$ fever and Rift Valley fever at the human and livestock interface in northern Côte d'Ivoire. Acta Tropica 165: 6675.

12. Kasymbekov J, Schelling E, Roth F, Zinsstag J (2014) Unpublished societal cost of brucellosis to Kyrgyzstan, p. 18.

13. Sokouri DP, Yapi-Gnaore CV, N'guetta ASP, Loukou NE, Kouao BJ, et.al (2010) Performances de reproduction des races bovines locales de Côte d'Ivoire. Journal of Applied Biosciences 36(4): 2353- 2359.

14. Mangen MJ, Otte J, Chilonda P, Pfeiffer J (2002) Bovine brucellosis in subSaharan Africa: Estimation of seroprevalence and impact on meat and milk offtake potential. WHO- Livestock Policy Discussion Paper No. 8.

15. Vandermeer JH, Goldberg DE (2013) Population Ecology: First Principles ( $2^{\text {nd }}$ edn.). 2013. Princeton University Press, Princeton, New Jersey, pp. 263.

16. Bernués A, Manrique, E, Maza MT (1997) Economic evaluation of bovine brucellosis and tuberculosis eradication programs in a mountain area of Spain. Preventive Veterinary Medicine 30(2): 137-149.

17. Tschopp R, Hattendorf J, Roth F, Choudhury AAK, Shaw A, et.al (2013) Cost estimate of bovine tuberculosis to Ethiopia. Current Topics in Microbiology and Immunology 365: 249-268.

18. Roth F, Zinsstag J, Orkhon D, Chimed-Ochir G, Hutton G, et.al (2003) Human health benefits from livestock vaccination for brucellosis: Case study. Bulletin of the World Health Organization 81(12): 867-876.

19. Godet G, Landais E, Poivey JP, Agabriel J, Mawudo W (1981) La traite et la production laitière dans les troupeaux villageois sédentaires au nord de la Côte d'Ivoire. Rev. Elev. Med Vet Pays Trop 34(1): 63-71.

20. Bouwman AF (1997) Long-term scenarios of livestock-crop-land use interactions in developing countries. FAO Land and Water Bulletin.

21. Schärrer S, Presi P, Hattendorf J, Chitnis N, Reist M, et.al (2014) Demographic model of the Swiss cattle population for the years 20092011 stratified by gender, age and production type. plos one $9(10)$ : e109329.

22. Upton M (1989) Livestock productivity assessment and herd growth models. Agricultural Systems 29 (2): 149-164.

23. Camus E (1980) Clinical incidence of bovine brucellosis in northern Ivory Coast. Revue D'élevage Et De Médecine Vétérinaire Des Pays Tropicaux 33(3): 263-269.

24. UNAIDS (2014) Côte d'Ivoire: HIV and AIDS Estimates. 
(c) (i) This work is licensed under Creative

To Submit Your Article Click Here: $\quad$ Submit Article

DOI: 10.32474/LOJNHC.2018.01.000124

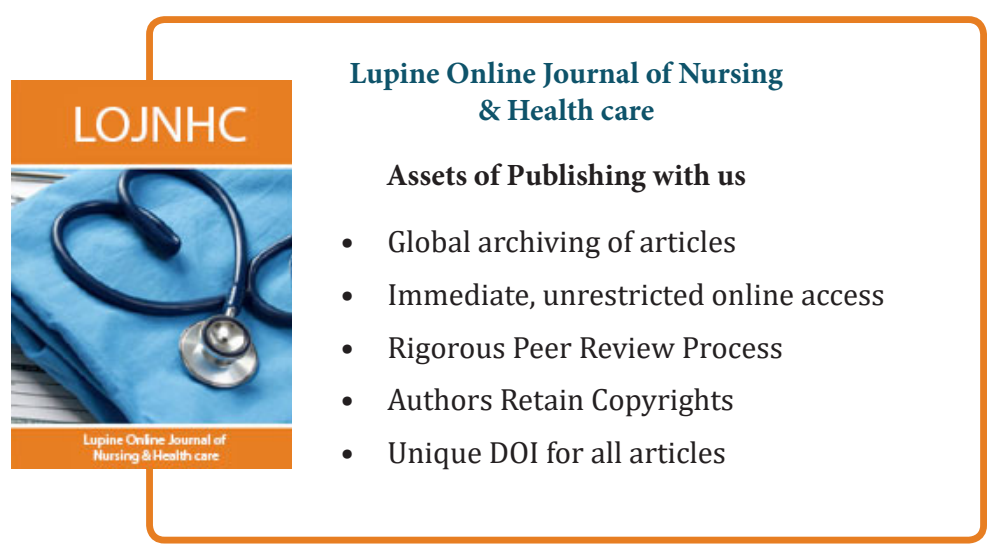

